\title{
Operation strategies to achieve low supply and return temperature in district heating system
}

\author{
Haoran $\mathrm{Li}^{1, *}$, and Natasa Nord ${ }^{1}$ \\ ${ }^{1}$ Department of Energy and Process Technology, Norwegian University of Science and Technology (NTNU), Kolbjørn Hejes vei 1 B, \\ Trondheim 7491, Norway
}

\begin{abstract}
Low temperature is the most significant feature of the future district heating (DH) - the 4th generation district heating $(4 \mathrm{GDH})$. The revolutionary temperature level $\left(50-55 / 25^{\circ} \mathrm{C}\right)$ will improve the efficiency of heat sources, thermal storages, and distribution systems, meanwhile, bring huge potentials to renewable energies. One challenge of transition to the future DH is the compatibility of current customer installations and the future temperature level. The aim of this study was to find the temperature potential of Norwegian residential buildings for the future DH system. A reference apartment was created, and typical space heating ( $\mathrm{SH}$ ) system was designed. A detailed building and $\mathrm{SH}$ system model were built in Modelica ${ }^{\circledR}$ language, and simulation was conducted via Dymola environment. Different operation strategies: PI control of the supply temperature, weather compensated control of the supply temperature, and PI control of the return temperature were tested. The results of the study showed the average supply temperature could be as low as $56 \sim 58^{\circ} \mathrm{C}$, and only limited time the temperature was above $60{ }^{\circ} \mathrm{C}$, when the controlled supply temperature strategies were applied. For the case with controlled return temperature strategies, the average return temperature were 30 and $37^{\circ} \mathrm{C}$, while the average required supply temperature could be 72 and $94^{\circ} \mathrm{C}$. The conclusion was that the low supply temperature could be achieved through optimized operation strategies. Whereas, the low return temperature was not able to be achieved only by improving the operation strategy.
\end{abstract}

\section{Introduction}

District heating $(\mathrm{DH})$ is an energy service, which moves the heat from available heat sources to customers. The fundamental idea of $\mathrm{DH}$ is to use local fuel or heat resources, which would otherwise be wasted, to satisfy local customer heat demands, by using heat distribution networks [1].

In historical development of $\mathrm{DH}$, the three generations of $\mathrm{DH}$ have been developed successively. The $1^{\text {st }}$ generation $\mathrm{DH}$ system uses steam as heat carrier. Almost all DH systems established until 1930 use this technology. The $2^{\text {nd }}$ generation $\mathrm{DH}$ system uses pressurized hot water as the heat carrier, with supply temperature mostly higher than $100^{\circ} \mathrm{C}$. These systems emerge in the 1930s and dominate all new systems until the 1970s. The $3^{\text {rd }}$ generation $\mathrm{DH}$ system still uses pressurized water as the heat carrier, but the supply temperatures are often below $100^{\circ} \mathrm{C}$. The system is introduced in the 1970s and take a major share of all extensions in the 1980s and beyond [2].

The direction of $\mathrm{DH}$ development has been in favour of lower distribution temperatures [1]. In addition, low temperature is the most significant feature of the future $\mathrm{DH}$ - the $4^{\text {th }}$ generation district heating $(4 \mathrm{GDH})$. The revolutionary temperature level $\left(50-55 / 25^{\circ} \mathrm{C}\right)$ will improve the efficiency of heat source, thermal storage, and distribution system, meanwhile, bring huge potential to renewable energies [3].

One challenge of transition to the future $\mathrm{DH}$ is the compatibility between current customer installation and future temperature level. Older buildings will continue to make up large share of building stock for many years (for Denmark and Norway, the share will be about 85$90 \%$ [4] and 50\% [5] in 2030, respectively). Those buildings are usually equipped with space heating $(\mathrm{SH})$ systems designed with supply temperature around $70^{\circ} \mathrm{C}$ or higher, thereby reduction of supply temperature would be expected to cause discomfort for the occupants [6]. However, studies show houses from the $70 \mathrm{~s}$ or $80 \mathrm{~s}$ without any renovation are possible to be heated with supply temperature of $50^{\circ} \mathrm{C}$ most of the year, and only limited time the supply temperature has to be above $60^{\circ} \mathrm{C}$. If original windows of the houses are replaced, it is possible to decrease the supply temperature to less than $60^{\circ} \mathrm{C}$ for almost the entire year $[4,7,8]$.

The aim of this study was to find the temperature potential of residential apartment buildings for the future DH systems in Norway. Reference apartment was created, and typical space heating $(\mathrm{SH})$ in the apartment was designed. Different operation strategies to achieve low supply and return temperature were tested. The results were used to analyse the possibilities and limitations of different control strategies.

\footnotetext{
*Corresponding author: haoranli@ntnu.no
} 


\section{Methodology}

\subsection{Reference apartment and weather data}

\subsubsection{Reference apartment}

Statistical data for Norwegian apartments constructed in different periods is presented in Table 1. Requirement development for the U-values for building envelop based on the Norwegian building code (TEK) are displayed in Fig. 1.

Table 1. Statistical data for Norwegian apartments [9].

\begin{tabular}{|c|c|c|}
\hline $\begin{array}{c}\text { Construction } \\
\text { period }\end{array}$ & $\begin{array}{c}\text { Number of } \\
\text { buildings }\end{array}$ & $\begin{array}{c}\text { Share of } \\
\text { percentage } \\
\text { (\%) }\end{array}$ \\
\hline Before 1956 & 161554 & 27 \\
\hline $1956 \sim 1970$ & 106324 & 18 \\
\hline $1971 \sim 1980$ & 90441 & 15 \\
\hline $1981 \sim 1990$ & 56379 & 9 \\
\hline $1991 \sim 2000$ & 63820 & 11 \\
\hline $2001 \sim 2010$ & 115080 & 19 \\
\hline
\end{tabular}

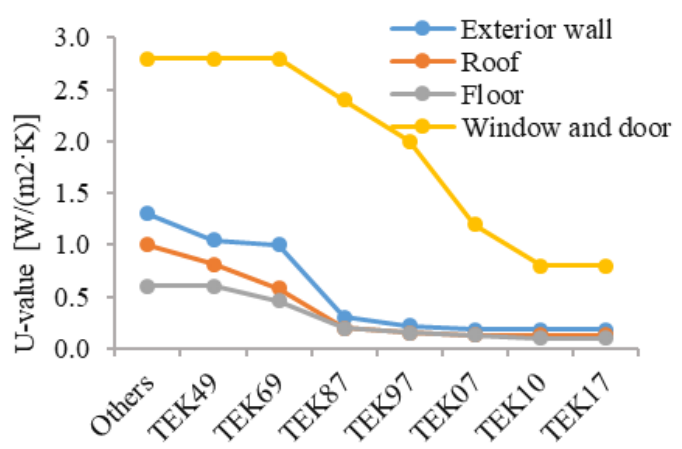

Fig. 1. Limit U-value of envelopes in developed Norwegian standards [9-11].

As Table 1 and Fig. 1 show, apartments built before 1990 account for about $70 \%$ of the total apartments, and the thermal requirement of envelopes during the years before 1990 show minor changes. Therefore, the apartment built around the years 1970s or 1980s can represent the thermal conditions of the majority of Norwegian apartments. In addition, the Norwegian building code TEK69 can be chosen as representative standard of the period.

The reference apartment was chosen from the middle floor of one building, there were five rooms: a living room, a children room, a bedroom, a bathroom, and a kitchen. The total floor area was about $70 \mathrm{~m}^{2}$. The condition of the reference apartment was selected based on the statistics of Norway, about $46 \%$ of the dwellings have $4-6$ rooms, and about $17 \%$ of the dwellings have the size of $60-79 \mathrm{~m}^{2}$ [12]. Detailed information of the apartment is listed in Table 2, and the sketch of the apartment is shown in Fig. 2.
Only natural ventilation was considered, and the air exchange rate was $0.51 / \mathrm{h}$, which is recommended $0.2 \sim 0.51 / \mathrm{h}$ in [9] and $0.51 / \mathrm{h}$ in the standard SNCEN/TR 12831 [13]. The set indoor air temperature in the living room, the children room, the bedroom, and the kitchen was $20^{\circ} \mathrm{C}$, which is the recommended value for category II in the standard EN 15251 [14]. For the bathroom, the set indoor air temperature value was $24^{\circ} \mathrm{C}$, considering the higher thermal comfort requirement.

Table 2. Thermal conditions of the reference apartment.

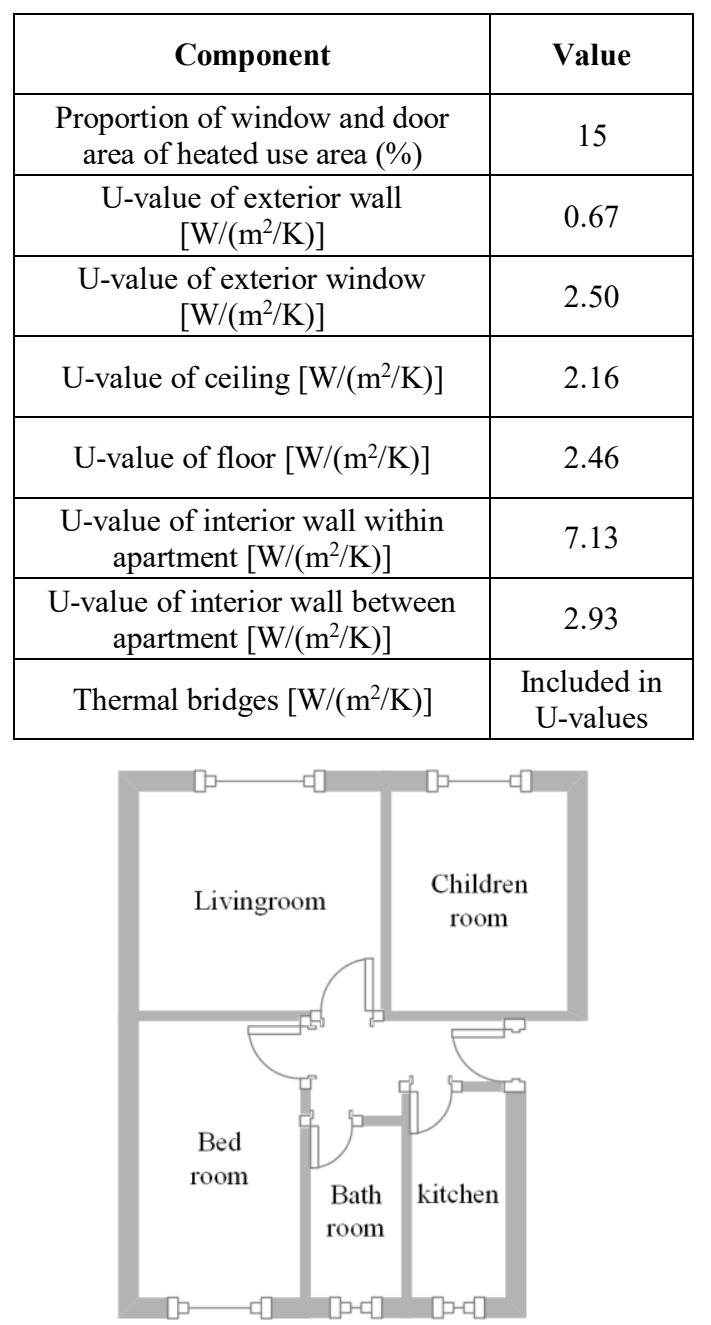

Fig. 2. Sketch map of the reference apartment.

The simulation result for the heat demand of the reference apartment was $121 \mathrm{~kW} \cdot \mathrm{h} /\left(\mathrm{m}^{2} \cdot\right.$ year $)$, which was close to $156 \mathrm{~kW} \cdot \mathrm{h} /\left(\mathrm{m}^{2} \cdot\right.$ year $)$ from a similar research [15].

\subsubsection{Weather data}

Test reference year (TRY) provides weather data for one year that characterize the local climatic conditions over a reasonably long period of time. TRY is widely adopted to get reliable simulation results [16]. The method to determine TRY is presented in ISO 15927-4 [17]. TRY for Trondheim, Norway was used in this study. The detail parameters for the air temperature, solar irradiance, and wind speed are shown in Fig. 3 . 

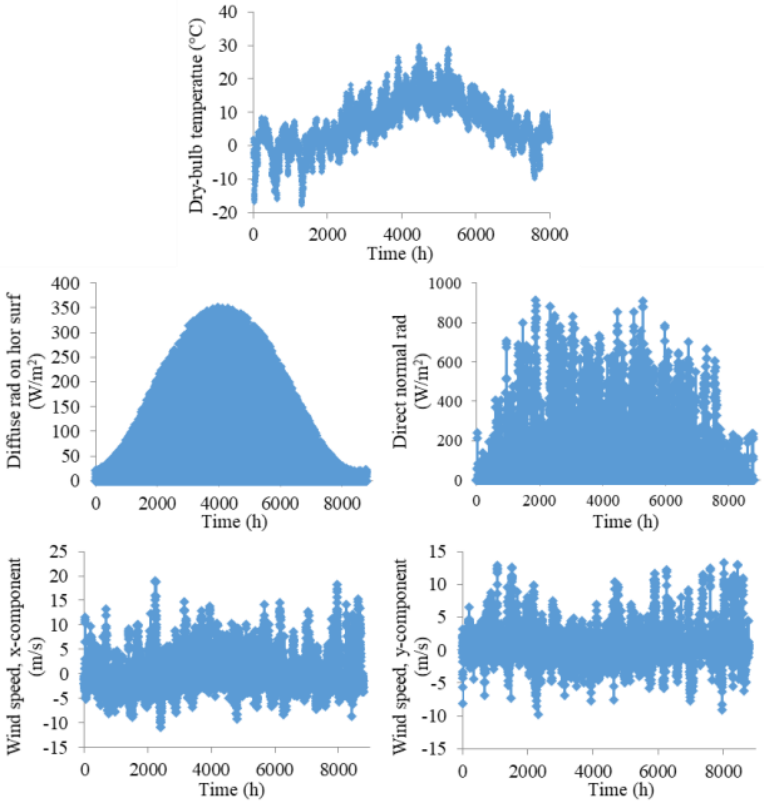

Fig. 3. TRY parameters of Trondheim, Norway.

\subsection{Building and heating system model}

\subsubsection{Language and simulation environment}

The model was built in Modelica ${ }^{\circledR}$ language [18], and the simulation was conducted via Dymola [19] environment. The components of the model were mainly from Modelica standard library [18], AixLib library [20], and Buildings library [21].

\subsubsection{Apartment model}

The apartment model was a high order model, which included all individual elements of envelopes and their spatial context. It could be used for in-depth analyses of building thermal behaviours. The overview of the apartment model is shown in Fig. 4.

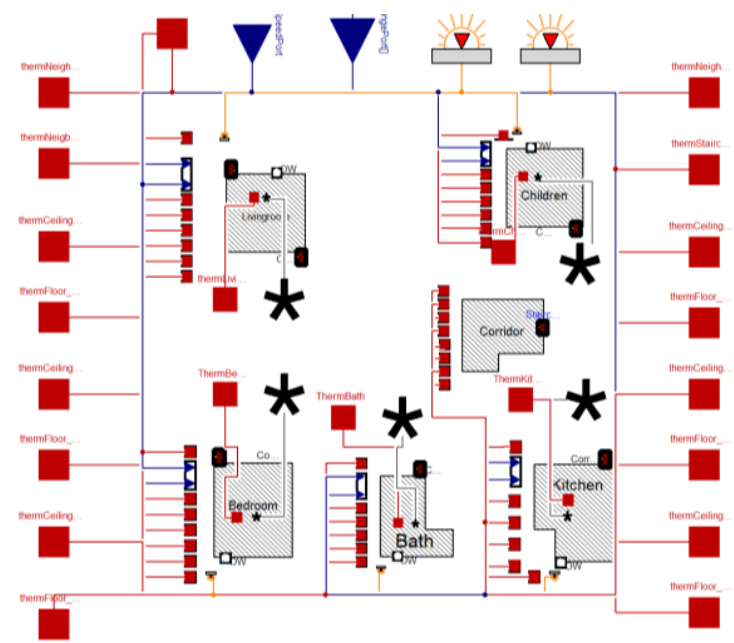

Fig. 4. Simplified overview of the building model.

For the submodule of each room, the following physical processes were considered: transient heat conduction through walls, steady-state heat conduction through glazing systems, radiation exchange between room facing elements. The detail information and evaluation work are presented in [22].

\subsubsection{Radiator model}

The radiator model is presented in Fig. 5. The calculation methods of convective and radiative heat transfer were described in $[23,24]$. The calculation of water pressure loss was illustrated in [25].
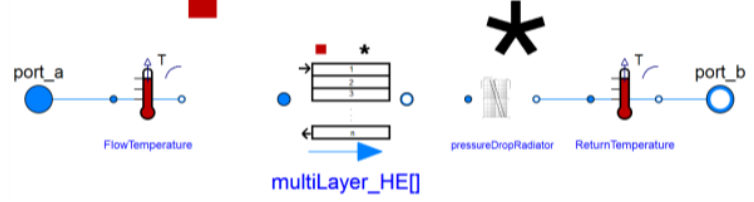

Fig. 5. Simplified overview of the radiator model.

The validation was conducted according to the standard EN 442-2 [26], and the simulation result was compared with the measured data from [27]. The results are presented in Fig. 6 .
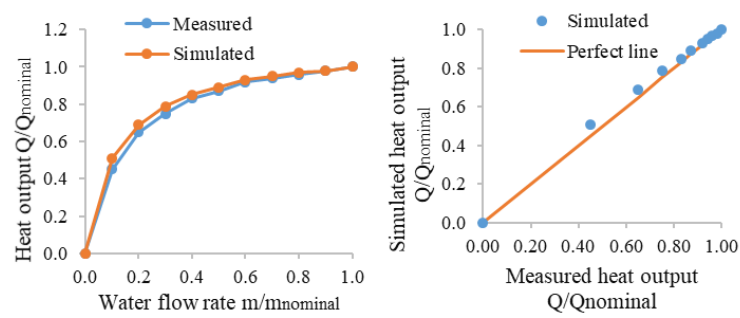

Fig. 6. Radiator heat output at different water flow rate at the operation condition $75 / 65 / 20^{\circ} \mathrm{C}$.

\subsubsection{Thermostatic valve model}

The behaviour of thermostatic valve (TV) depends on the characteristic of TV as well as the overall system. Both of them should be taken into account to build the TV model [28]. According to the standard EN215 [29] and researches in $[28,30]$, the water flow rate through the TV depends on the difference between measured indoor air temperature and the closing temperature or opening temperature of TV. To simplify the control process, proportional integral (PI) controller is applied to approximate the performance of the TV in $[31,32]$. The PI controller in the TV model is shown in Fig. 7.

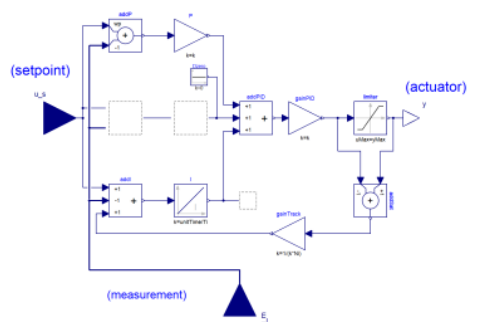

Fig. 7. Overview of the PI controller in TV model. 


\subsubsection{Space heating system model}

The overview of the SH system is presented in Fig. 8. For each room one radiator was designed to satisfy the heat demand. Heat demand of each room during heating season and heat output of corresponding radiator at nominal condition are shown in Fig. 9. According to the standard SN-CEN/TR 12831 [13], the outdoor design temperature for heat load calculation is $-12{ }^{\circ} \mathrm{C}$, and the sizing of system is based on the calculated heat load. The room heat loads, nominal heat output of radiators, and system oversizing values are listed in Table 3 . The oversizing values in this study agree with the median oversizing values from one investigation research, which is range from $15 \%$ to $25 \%$ [33] .

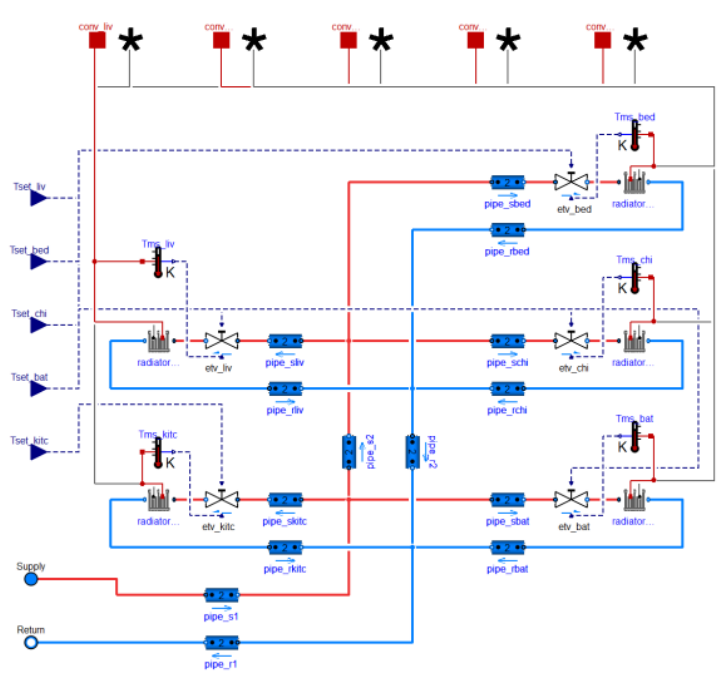

Fig. 8. Overview of the space heating system.
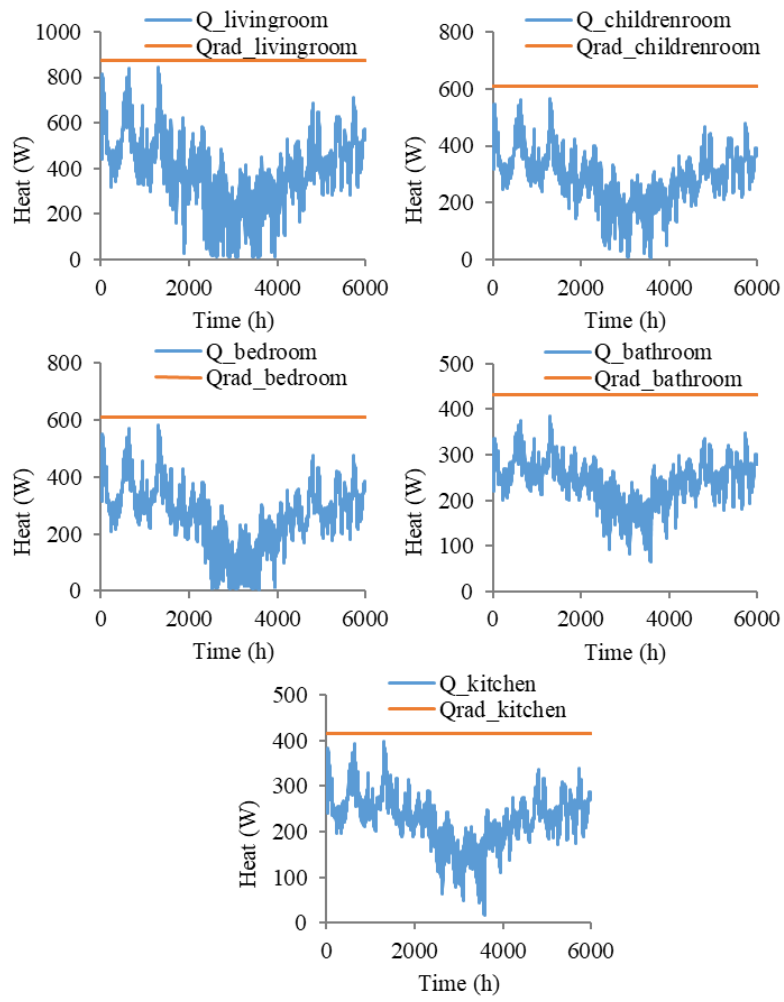

Fig. 9. Room heat demand during heating season and radiator heat output at nominal condition.
Table 3. Room heat load and Radiator design.

\begin{tabular}{|c|c|c|c|}
\hline Room & $\begin{array}{c}\text { Room heat } \\
\text { load (W) }\end{array}$ & $\begin{array}{c}\text { Radiator } \\
\text { heat output } \\
\text { (W) }\end{array}$ & $\begin{array}{c}\text { Oversizing } \\
\text { (\%) }\end{array}$ \\
\hline Living room & 770 & 874 & 14 \\
\hline $\begin{array}{c}\text { Children } \\
\text { room }\end{array}$ & 520 & 608 & 17 \\
\hline Bedroom & 520 & 608 & 17 \\
\hline Bathroom & 352 & 431 & 22 \\
\hline Kitchen & 360 & 415 & 15 \\
\hline
\end{tabular}

\subsection{Scenarios}

The considerations of different scenarios are listed as follows:

-The scenarios with low return temperature: Low supply and return temperature reduce the costs of heat generation and distribution. Some DH companies incentivize their customers through motivation tariffs to reduce their temperatures in exchange of discount in their energy bills. Researches show that low return temperature has higher economic benefits, and $\mathrm{DH}$ companies care more about low return temperature than low supply temperature [34].

-The scenarios with low supply temperature: In the future, more renewables will be integrated into $\mathrm{DH}$ system. Low supply temperature will increase output of solar energy, raise coefficient of performance for heat pumps, and increase the power to heat ratio of combined heat and power plans [3].

-The scenarios with minimum supply temperature: The favourable conditions for legionella proliferation ranging from 25 to $45^{\circ} \mathrm{C}$ [35]. In the European standard CEN/TR16355 [36], drinking water installation without hot water circulation, should be capable of reaching the minimum of $55^{\circ} \mathrm{C}$. For a drinking water installation with circulation, should be the minimum of $55{ }^{\circ} \mathrm{C}$, and within $30 \mathrm{~s}$ after fully opening a draw off fitting the temperature should not be less than $60^{\circ} \mathrm{C}$. Meanwhile, to decrease the required temperature, some researches recommend to use supplementary heating devices, and the supply temperature can be decreased to $40^{\circ} \mathrm{C}$ [35].

In this study, six scenarios were proposed, see Table 4. For those scenarios, the controlled supply or return temperature were adjusted once in an hour, based on outdoor temperature, or the difference between the set and the measured indoor air temperature. Meanwhile, the maximum supply temperature for all the scenarios was $130^{\circ} \mathrm{C}$.

For the theoretical calculation marked with TC in Table 4, the supply temperature was calculated based on equation (11-14) in [25], which is widely applied when the weather compensation (WC) control is used:

$$
T_{\mathrm{s}}=20+10 \cdot\left(20-T_{\text {out }}\right)^{0.45}+0.14 \cdot\left(20-T_{\text {out }}\right)
$$

where $T_{\mathrm{s}}$ is the supply water temperature $\left({ }^{\circ} \mathrm{C}\right), T_{\text {out }}$ is the outdoor air temperature $\left({ }^{\circ} \mathrm{C}\right)$. 
Table 4. Information of the six scenarios.

\begin{tabular}{|c|c|}
\hline Scenario & Description \\
\hline TS_PI_NL & $\begin{array}{c}\text { Supply temperature control via PI } \\
\text { controller with no minimum } \\
\text { temperature limit }\end{array}$ \\
\hline TS_PI_WL & $\begin{array}{c}\text { Supply temperature control via PI } \\
\text { controller with minimum temperature } \\
\text { limit of 50 }{ }^{\circ} \mathrm{C}\end{array}$ \\
\hline TS_TC_NL & $\begin{array}{c}\text { Supply temperature control via } \\
\text { theoretical calculation with no } \\
\text { minimum temperature limit }\end{array}$ \\
\hline TS_TC_WL & $\begin{array}{c}\text { Supply temperature control via } \\
\text { theoretical calculation with minimum } \\
\text { temperature limit of } 50^{\circ} \mathrm{C}\end{array}$ \\
\hline TR_PI_TC & $\begin{array}{c}\text { Return temperature control via PI } \\
\text { controller with constant target } \\
\text { temperature of } 30^{\circ} \mathrm{C}\end{array}$ \\
\hline TR_PI_TV & $\begin{array}{c}\text { Return temperature control via PI } \\
\text { controller with variable target } \\
\text { temperature ranges from } 30 \text { to } 50^{\circ} \mathrm{C}\end{array}$ \\
\hline
\end{tabular}

\section{Results}

The system supply and return temperature during heating season are presented in Fig. 10. The relation between the average supply temperature, the average return temperature, and the average temperature difference during heating season is shown in Fig. 11. The indoor air temperatures for different scenarios are shown in Fig. 12. The total heat rates of the flat for different scenarios are displayed in Fig. 13. A summary of all the results is given in Table 5.

As Fig. 10 and Table 5 show, the low supply temperature was achieved via the PI control in the scenarios TS_PI_NL and TS_PI_WL, and with the WC control in the scenarios TS TC NL and TS TC WL. The average supply temperature in those scenarios could be as low as $56 \sim 58^{\circ} \mathrm{C}$, and only limited time the required supply temperature was above $60^{\circ} \mathrm{C}$. In addition, compared with the WC control, the PI control shown an advantage lowering the supply temperature. The percentage of required supply temperature above $60^{\circ} \mathrm{C}$ was $17 \%$ when the PI controllers were applied, while, the corresponding value was $36 \%$ in the case of the WC controls. The reason was that the WC control is an open loop control strategy and the supply temperature is only decided by the outdoor air temperature, ignoring any other impact factors, such as heat gain from solar radiation, occupant, and other devices. Whereas, the PI controller is a feedback control strategy and any overheating caused by extra heat gain will be compensated by the change in the supply temperature. In that way, unnecessary high supply temperatures are avoided. In this study, heat gains from occupants and devices were not taken into account, even though they might show more advantages for the PI controller. This model extension will be a topic for the future work.

As Fig. 10 and Table 5 show, the low return temperature was achieved through the PI controller in the scenarios TR PI TC and TR PI TV. The average return temperature in those scenarios were 30 and $37^{\circ} \mathrm{C}$ respectively, and the temperature below $40^{\circ} \mathrm{C}$ covers most of the heating season, with share of $99 \%$ and $83 \%$, respectively. However, one obvious disadvantage for those operation strategies was the high supply temperature. The average supply temperature in the scenario TR PI_TC was $94^{\circ} \mathrm{C}$, and sometimes in order to achieve the low target return temperature, the required supply temperature was even up to $130^{\circ} \mathrm{C}$. One way to solve this issue is to use flexible target return temperature. Compared with the scenario TR PI TC with constant target return temperature, TR_PI_TV uses flexible target return temperature. The average supply temperature of the scenario TR_PI_TV decreased to $72^{\circ} \mathrm{C}$, meanwhile the maximum supply temperature decreases to $111^{\circ} \mathrm{C}$.

As Fig. 10, Fig. 11, and Table 5 show, there is a clear relation between the supply temperature, the return temperature, and the temperature difference.
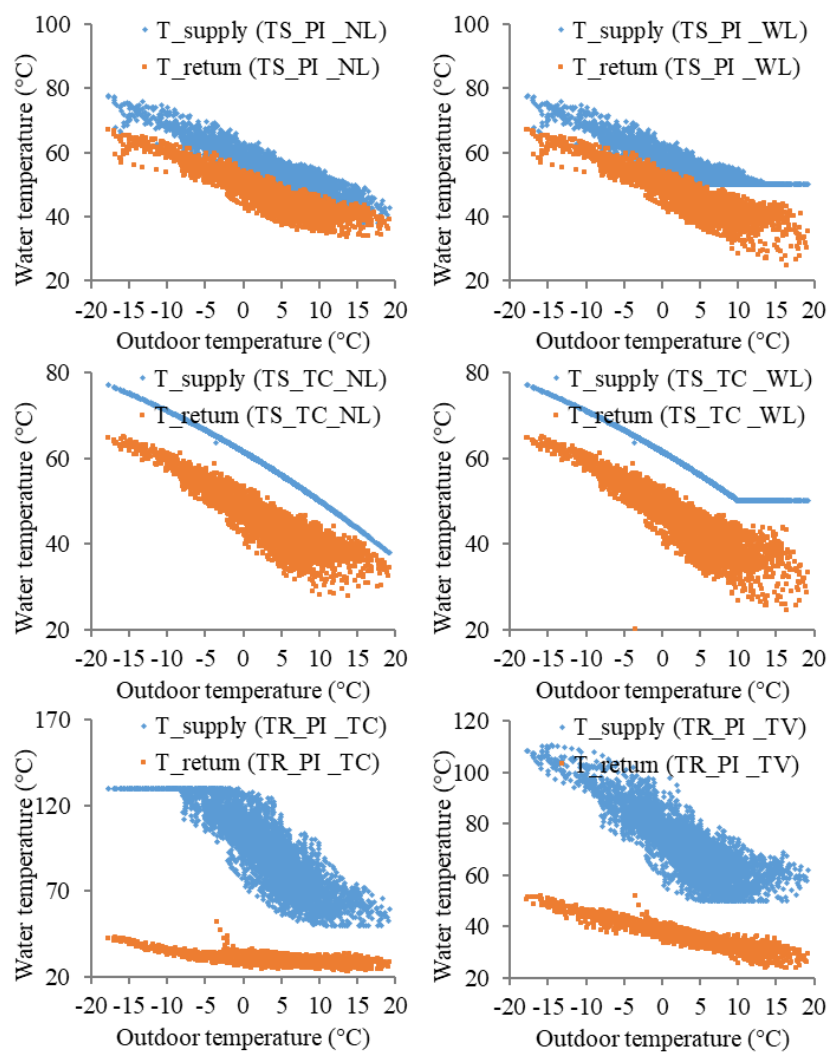

Fig. 10. Supply and return temperature during heating season.

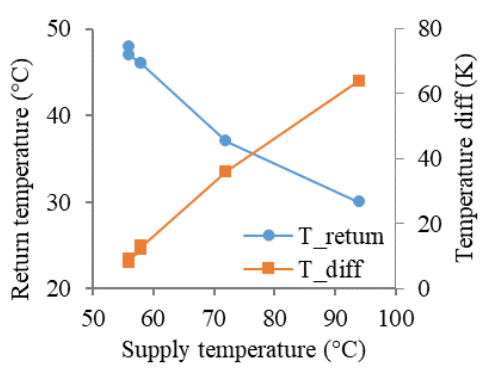

Fig. 11. The relation between average supply temperature, return temperature, and temperature difference. 
As shown in Fig. 12 and Table 5, different operation strategies show small differences in the indoor air temperature. During most of the heating season, 98 99\% of the entire season, the range of the indoor air temperature is within $\pm 0.5^{\circ} \mathrm{C}$ around the set value. In addition, the results reveal the importance of indoor temperature control device, specifically TVs. Wellfunctioning TVs guarantee the indoor air temperature fluctuating within a certain range around the set values, no matter what operation strategy was applied. On the contrary, the indoor air temperature and the system return temperature would be with fault when the TVs have malfunctions [37, 38].
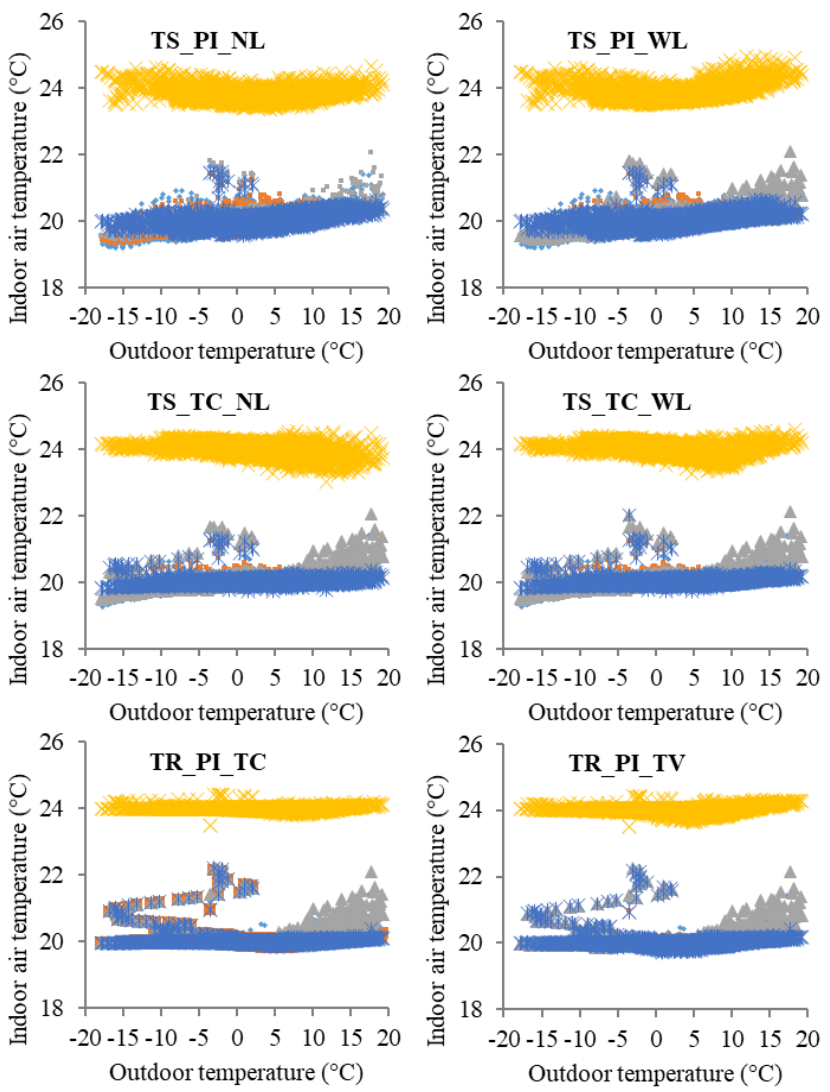

Fig. 12. Indoor temperature during heating season. The yellow dots present temperature of bathroom with setting temperature of $24^{\circ} \mathrm{C}$, other color dots present temperature of living room, children room, bedroom, and kitchen with setting temperature of $20^{\circ} \mathrm{C}$

As shown in Fig. 13 and Table 5, different operation strategies show little difference on apartment heat use. As mentioned before, heat gains from occupants and devices were not taken into account in this study, otherwise energy savings from the PI controls would become bigger. More advanced control strategy, such as model predictive control (MPC) can bring even more energy savings and make the control process more smooth [39].
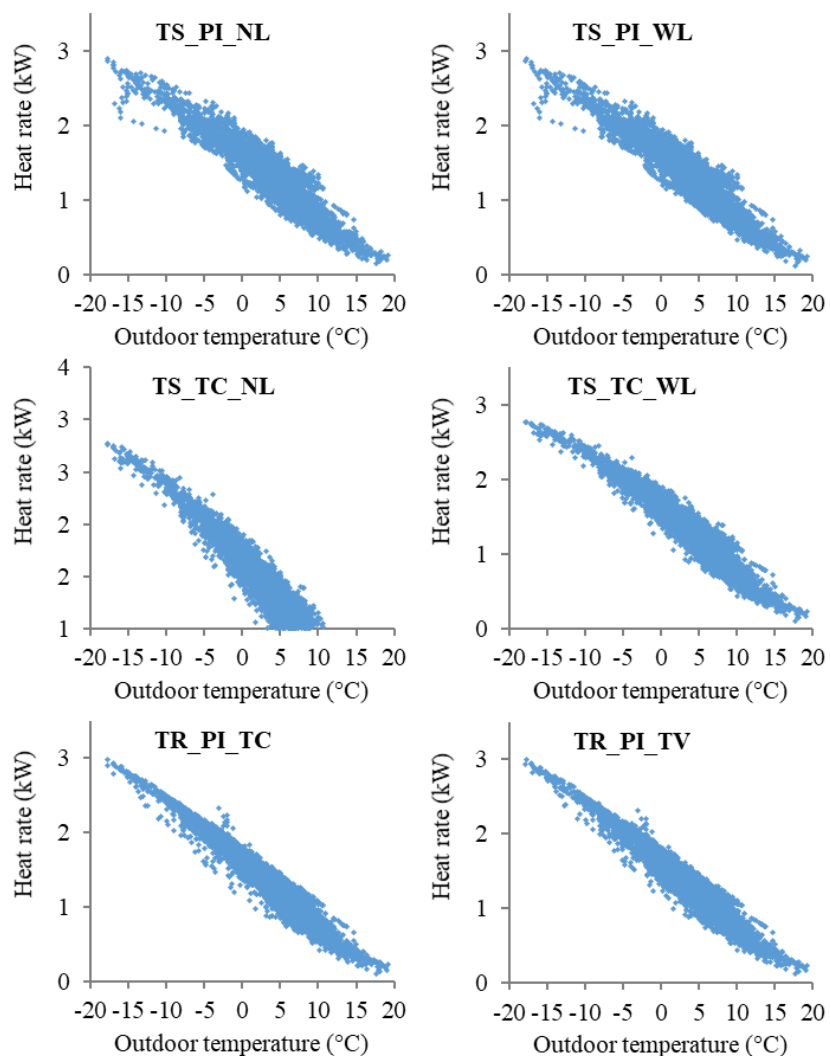

Fig. 13. Heat use during heating season.

Table 5. Summarized outcomes of different scenarios.

\begin{tabular}{|c|c|c|c|c|c|c|}
\hline Scenario & $\begin{array}{l}\text { TS_ } \\
\text { PI_- } \\
\text { NL }\end{array}$ & $\begin{array}{l}\text { TS_- } \\
\text { PI_- } \\
\text { WL }\end{array}$ & $\begin{array}{l}\text { TS } \\
\text { PI_- } \\
\text { WL }\end{array}$ & $\begin{array}{l}\text { TS_ } \\
\text { TC_- } \\
\text { NL }\end{array}$ & $\begin{array}{l}\text { TR } \\
\text { PI }^{-} \\
\text {TC }\end{array}$ & $\begin{array}{l}\text { TR } \\
\text { PI } \\
\text { TV } \\
\end{array}$ \\
\hline \multicolumn{7}{|c|}{ Supply temperature } \\
\hline $\operatorname{Max}\left({ }^{\circ} \mathrm{C}\right)$ & 78 & 78 & 77 & 77 & 130 & 111 \\
\hline $\operatorname{Min}\left({ }^{\circ} \mathrm{C}\right)$ & 38 & 50 & 38 & 50 & 50 & 50 \\
\hline $\begin{array}{c}\text { Average } \\
\left({ }^{\circ} \mathrm{C}\right)\end{array}$ & 56 & 56 & 58 & 58 & 94 & 72 \\
\hline$>60(\%)$ & 17 & 17 & 36 & 36 & 96 & 87 \\
\hline \multicolumn{7}{|c|}{ Return temperature } \\
\hline $\operatorname{Max}\left({ }^{\circ} \mathrm{C}\right)$ & 67 & 67 & 65 & 65 & 52 & 52 \\
\hline $\operatorname{Min}\left({ }^{\circ} \mathrm{C}\right)$ & 34 & 25 & 28 & 20 & 23 & 24 \\
\hline $\begin{array}{c}\text { Average } \\
\left({ }^{\circ} \mathrm{C}\right)\end{array}$ & 48 & 47 & 46 & 46 & 30 & 37 \\
\hline$<40(\%)$ & 6 & 7 & 15 & 16 & 99 & 83 \\
\hline \multicolumn{7}{|c|}{ Temperature difference } \\
\hline $\begin{array}{c}\text { Average } \\
\left({ }^{\circ} \mathrm{C}\right)\end{array}$ & 8 & 9 & 12 & 13 & 64 & 36 \\
\hline \multicolumn{7}{|c|}{ Indoor temperature (\%) } \\
\hline$<$ set- 0.5 & 1 & 0 & 0 & 0 & 0 & 0 \\
\hline $\begin{array}{c}\text { Within } \\
\text { set } \pm 0.5 \\
\end{array}$ & 98 & 98 & 99 & 99 & 99 & 99 \\
\hline$>$ set +0.5 & 1 & 1 & 1 & 1 & 1 & 1 \\
\hline
\end{tabular}




\begin{tabular}{|c|c|c|c|c|c|c|}
\hline Scenario & $\begin{array}{l}\text { TS } \\
\text { PI }_{-} \\
\text {NL }^{-}\end{array}$ & $\begin{array}{l}\text { TS } \\
\text { PI }_{-} \\
\text {WL }\end{array}$ & $\begin{array}{l}\text { TS } \\
\text { PI }_{-} \\
\text {WL }\end{array}$ & $\begin{array}{l}\text { TS } \\
\text { TC } \\
\mathrm{NL}_{-}\end{array}$ & $\begin{array}{l}\mathrm{TR}_{-} \\
\mathrm{PI}_{-} \\
\mathrm{T}_{\mathrm{C}}\end{array}$ & $\begin{array}{l}\text { TR } \\
\text { PI }_{-} \\
\text {TV }\end{array}$ \\
\hline \multicolumn{7}{|c|}{ Heat use per year } \\
\hline $\begin{array}{c}\text { Total } \\
(\mathrm{kWh})\end{array}$ & 8427 & 8435 & 8470 & 8477 & 8478 & 8478 \\
\hline $\begin{array}{c}\text { Index } \\
\left(\mathrm{kWh} / \mathrm{m}^{2}\right)\end{array}$ & 120 & 121 & 121 & 121 & 121 & 121 \\
\hline
\end{tabular}

\section{Conclusion and discussion}

This study aimed to optimize the operation strategy, and achieve the low supply and return temperature of the DH system. A building and a SH model were built using Modelica ${ }^{\circledR}$ language, and simulation was conducted in Dymola environment. Six scenarios, with controlled supply temperature or return temperature, were analysed based on the model.

The low supply temperature was achieved through the controlled supply temperature operation strategies: the PI control and the WC control. The average supply temperature could be as low as $56 \sim 58^{\circ} \mathrm{C}$, and only limited time the required supply temperature was above $60^{\circ} \mathrm{C}$, with $17 \%$ and $36 \%$ of the heating season, respectively. Meanwhile, the low return temperature was achieved through controlled return temperature operation strategy, the PI control. The average return temperature could be 30 or $37^{\circ} \mathrm{C}$, while the temperature below $40^{\circ} \mathrm{C}$ covered the most time of heating season, with share of $99 \%$ and $83 \%$, respectively.

One question come from this study, whether it is possible to achieve the low return temperature through optimizing operation strategy, without inappropriate high supply temperature. The results showed a clear coupling among the supply temperature, the return temperature, and the temperature difference between them. When the strategy with the constant target return temperature of $30^{\circ} \mathrm{C}$ was applied, the average supply temperature was $94^{\circ} \mathrm{C}$, and during the coldest days, it was even up to $130^{\circ} \mathrm{C}$, which is too high for the secondary side of $\mathrm{DH}$ system. One way to mitigate this issue was using flexible target return temperature. After the flexible target return temperature from 30 to $50^{\circ} \mathrm{C}$ was applied, the average supply temperature decreased to $72^{\circ} \mathrm{C}$, and the maximum supply temperature decreased to $111^{\circ} \mathrm{C}$. The results were still some distance from the temperature requirement of $4 \mathrm{GDH}$, which is $50-55^{\circ} \mathrm{C}$ for the supply temperature, and $25^{\circ} \mathrm{C}$ for the return temperature. However, please note that the results are valid for the existing apartment building, built before 1980s and not for new buildings.

Another conclusion was the importance of TVs. Different operation strategies in this study showed small differences in the indoor air temperature and heat use. During the heating season, about $98 \sim 99 \%$ of the time, the fluctuation of the indoor air temperature was within $\pm 0.5{ }^{\circ} \mathrm{C}$ around the set value. The results revealed the importance of TVs, which was the critical device to prevent overheating.

There were some limitations in this study. Renovations of buildings is a critical influencing factor in building energy analyses. Buildings have gone through reasonable renovations, such as changing the windows, use less heat and require a lower supply temperature. Building renovation was not taken into account in this study. In addition, the average heat gains from occupants and equipment can be assumed as 0.81 and $1.55 \mathrm{~W} / \mathrm{m}^{2}$ respectively [34]. If those heat gains were added, the oversizing of radiators would increase $5 \sim 10 \%$, the final value of oversizing will range from 21 to $27 \%$. Under such condition, the required supply temperature could be further lower. Meanwhile, simplified occupant behavior mode was applied in this study, with constant set indoor temperature and fixed air exchange rate. Studies show occupant behaviour influence building energy use [40-42]. The simplification of the model may cause some inconsistent between simulation and reality. Finally, the research was conducted based on the simulation of two pipe $\mathrm{SH}$ system in an apartment with five rooms. To obtain more general and proper conclusions, further researches and experimentation studies are needed.

The authors gratefully acknowledge the support from the Research Council of Norway through the research project Understanding behaviour of district heating systems integrating distributed sources under FRIPRO/FRINATEK program (the project number 262707).

\section{References}

[1] Frederiksen S, Werner S. District Heating and Cooling: Studentlitteratur, 2013.

[2] Lund H, Werner S, Wiltshire R, Svendsen S, Thorsen JE, Hvelplund F, et al. 4th Generation District Heating (4GDH) Integrating smart thermal grids into future sustainable energy systems. Energy. 2014;68:1-11.

[3] Li H, Nord N. Transition to the 4th generation district heating-possibilities, bottlenecks, and challenges. Energy Procedia. 2018;149:483-98.

[4] Lund H, Möller B, Mathiesen BV, Dyrelund A. The role of district heating in future renewable energy systems. Energy. 2010;35(3):1381-90.

[5] IEA. Future low temperature district heating design guidebook. In: Schmidt D, Kallert A, editors. AGFWProject Company Stresemannallee, Germany: International Energy Agency Technology Collaboration Programme on District Heating and Cooling including Combined Heat and Power; 2017.

[6] Brand M, Svendsen S. Renewable-based lowtemperature district heating for existing buildings in various stages of refurbishment. Energy. 2013;62:311-9.

[7] Nord N, Ingebretsen M, Tryggestad I. Possibilities for Transition of Existing Residential Buildings to Low Temperature District Heating System in Norway. Conference Possibilities for Transition of Existing Residential Buildings to Low Temperature District Heating System in Norway. p. 22-5.

[8] Østergaard DS, Svendsen S. Theoretical overview of heating power and necessary heating supply temperatures in typical Danish single-family houses from the 1900s. Energy and Buildings. 2016;126:375-83. [9] AS P, AS E. Potential and barrier study- Energy efficiency of Norwegian buildings (in Norwegian). 2012. 
[10] Administration TNOoBTa. Guidance on technical requirements for construction work- Building Technology Regulations (TEK17) with guidance (in Norwegian) 2017.

[11] Administration TNOoBTa. Guidance on technical requirements for construction work- Building Technology Regulations (TEK10) with guidance (in Norwegian) 2010.

[12] Housing conditions, survey on living conditions, https://www.ssb.no/en/bygg-bolig-og-

eiendom/statistikker/bo. 2019.

[13] CEN. SN-CEN / TR 12831-2: Energy Performance of Buildings - Method of Calculating Dimensional Power Requirements for Heat - Part 2: Explanation and Explanation of NS-EN 12831-1, Module M3-3. 2017.

[14] CEN. NS-EN 15251: Indoor environmental input parameters for design and assessment of energy performance of buildings addressing indoor air quality, thermal environment, lighting and acoustics. 2014.

[15] Ingebretsen ME. Possibilities for transition of existing buildings to low temperature district heating (in Norwegian): Norwegian University of Science and Technology, 2014.

[16] Kim S, Zirkelbach D, Künzel HM, Lee J-H, Choi J. Development of test reference year using ISO 15927-4 and the influence of climatic parameters on building energy performance. Building and Environment. 2017;114:374-86.

[17] Standardization ECf. EN ISO 15927-42005: Hygrothermal Performance of Buildings-Calculation and Presentation of Climatic Data-Part 4 Hourly Data for Assessing the Annual Energy Use for Heating and Cooling. 2005.

[18] Modelica and the Modelica Association, https://www.modelica.org/. 2019.

[19] CATIA SYSTEMS ENGINEERING - DYMOLA, https://www.3ds.com/products-

services/catia/products/dymola/key-advantages/. 2019.

[20] Müller D, Lauster M, Constantin A, Fuchs M, Remmen P. AixLib-An Open-Source Modelica Library within the IEA-EBC Annex 60 Framework. BauSIM 20162016. p. 3-9.

[21] Open source library for building energy and control systems, https://simulationresearch.lbl.gov/modelica/. 2019.

[22] Constantin A, Streblow R, Müller D. The modelica housemodels library: Presentation and evaluation of a room model with the ASHRAE Standard 140. Conference The modelica housemodels library: Presentation and evaluation of a room model with the ASHRAE Standard 140. Linköping University Electronic Press, p. 293-9.

[23] Tritschler M. Assessment of the accuracy of heat cost allocators (in German): University of Stuttgart, 1999. [24] Gluck B. Heat transfer: Heat dissipation of space heating surfaces and pipes (in German): Verlag für Bauwesen Berlin, 1990.

[25] He P, Sun G, Wang F, Wu H, WU X. Heating engineering (in Chinese): China Architecture \& Building Press, 2009.

[26] CEN. EN 442-2: Radiators and Convectors-Part 2: Test Methods and Rating. 2003.
[27] Prek M, Krese G. Experimental analysis of an improved regulation concept for multi-panel heating radiators: Proof-of-concept. Energy. 2018;161:52-9.

[28] Seifert J, Knorr M, Meinzenbach A, Bitter F, Gregersen N, Krogh T. "Review of thermostatic control valves in the European standardization system of the EN 15316-2/EN 215". Energy and Buildings. 2016;125:5565.

[29] CEN. EN215: Thermostatic Radiator ValvesRequirements and Test Methods. 2004.

[30] Xu B, Fu L, Di H. Dynamic simulation of space heating systems with radiators controlled by TRVs in buildings. Energy and Buildings. 2008;40(9):1755-64.

[31] Wang Y, You S, Zheng X, Zhang H. Accurate model reduction and control of radiator for performance enhancement of room heating system. Energy and Buildings. 2017;138:415-31.

[32] Tahersima F, Stoustrup J, Rasmussen H. An analytical solution for stability-performance dilemma of hydronic radiators. Energy and Buildings. 2013;64:43946.

[33] Østergaard DS, Svendsen S. Are typical radiators over-dimensioned? An analysis of radiator dimensions in 1645 Danish houses. Energy and Buildings. 2018;178:206-15.

[34] Tunzi M, Østergaard DS, Svendsen S, Boukhanouf $\mathrm{R}$, Cooper E. Method to investigate and plan the application of low temperature district heating to existing hydraulic radiator systems in existing buildings. Energy. 2016;113:413-21.

[35] Yang X, Li H, Svendsen S. Evaluations of different domestic hot water preparing methods with ultra-lowtemperature district heating. Energy. 2016;109:248-59.

[36] CEN. CEN/TR16355: Recommendations for prevention of Legionella growth in installations inside buildings conveying water for human consumption. 2012. [37] Østergaard DS, Svendsen S. Experience from a practical test of low-temperature district heating for space heating in five Danish single-family houses from the 1930s. Energy. 2018;159:569-78.

[38] Peffer T, Pritoni M, Meier A, Aragon C, Perry D. How people use thermostats in homes: A review. Building and Environment. 2011;46(12):2529-41.

[39] Prívara S, Široký J, Ferkl L, Cigler J. Model predictive control of a building heating system: The first experience. Energy and Buildings. 2011;43(2):564-72.

[40] Nord N, Tereshchenko T, Qvistgaard LH, Tryggestad IS. Influence of occupant behavior and operation on performance of a residential Zero Emission Building in Norway. Energy and Buildings. 2018;159:75-88.

[41] D'Oca S, Hong T, Langevin JJR, Reviews SE. The human dimensions of energy use in buildings: A review. 2018;81:731-42.

[42] Sun K, Hong T. A framework for quantifying the impact of occupant behavior on energy savings of energy conservation measures. Energy and Buildings. 2017;146:383-96. 